\title{
Cyclic AMP-Responsive Element-Binding Protein 3-Like Protein 1
}

National Cancer Institute

\section{Source}

National Cancer Institute. Cyclic AMP-Responsive Element-Binding Protein 3-Like Protein

1. NCI Thesaurus. Code C95479.

Cyclic AMP-responsive element-binding protein 3-like protein 1 (519 aa, 57 kDa) is encoded by the human CREB3L1 gene. This protein plays a role in the unfolded protein response. 